\title{
Exposure of children to lead in Uganda
}

\author{
D. BARLTROP, G. V. COLES, and R. A. McCANCE \\ From the Paediatric Unit, St. Mary's Hospital Medical School, London; British Railways Board, Medical Depart- \\ ment, Muswell Hill, London; and Sidney Sussex College, Cambridge
}

\begin{abstract}
Barltrop, D., Coles, G. V., and McCance, R. A. (1973). Archives of Disease in Childhood, 48, 642. Exposure of children to lead in Uganda. Lead was determined in the faeces of 4 healthy Ugandan children. Three of the specimens indicated some exposure to lead and one of them contained excessive amounts. Subsequent examination of the foods grown and eaten at this child's home suggested that they contained undesirable amounts of lead. Bones were therefore obtained at 21 necropsies on children at Mulago Hospital, but the amounts of lead found in them did not significantly exceed those found in a control group of British children.
\end{abstract}

Lead poisoning in childhood is usually considered to be a disorder of the developed countries associated with lead paint, though numerous other causes are recognized. Lead pipes, conduits, and domestic utensils, for example, have been a danger, probably since Roman times. Occupational exposures to lead in industrial employees in Uganda have become relatively common, and a desire to find out something about the amount of lead in Ugandans without occupational exposure suggested to one of us (R.A.M.) that this might be achieved by investigating children in the region near Kampala. Anaemia and irritability are common in children with nutritional deficiencies and are also, though nonspecifically, associated with lead intoxication (Barltrop, 1968). Lead encephalopathy has not been reported in Uganda.

Lead paint on structures is not likely to be a common cause of lead poisoning in rural areas, but glazed earthenware requires consideration since lead glazes may be used in cottage industries where high firing temperatures cannot be obtained. Galena (lead sulphide) occurs in surface outcrops in at least one district of Uganda and has been used as a finish for pottery vessels. Local drinking water is unlikely to increase the lead intakes since only one such supply in Uganda (not near Kampala) has been shown to have a lead content which would be considered high by reference to British Standards (H. A. Harbottle, personal communication, 1968). Enamelled metal holloware, locally manufactured, is known to be made with lead-free frits, but some of

Received 4 December 1972. the cheaper imported goods may have been made with lead-containing enamels. In the peri-urban areas, however, other domestic exposures to lead are possible. Thus the use of scrap battery boxes as fuel, and the burning of scrapped motor tyres, perhaps made from rubbers with lead additives, are possible sources of domestic lead exposure.

Lead is used in several industrial applications in Uganda and is found in dross from type-metal pots containing lead in printing establishments (now a long established activity), in dusts from a multiplicity of soldering operations in light industry, in dross from lead heat-treating baths for tempering steel baling-strip, and in dust from the dressing of solder fillings in repaired motor vehicles. Batteries for motor vehicles were, until recently, imported as finished products, but are now manufactured locally. Previous investigations by the Uganda Factories Inspectorate have revealed unsatisfactory working conditions in some of the undertakings where the repair and scrapping of batteries were being carried out, and biological indices of increased exposure to lead were found among employees (Coles, 1960). Though these sources are unlikely to involve children directly, it is increasingly recognized that industrial clothing may serve as a vehicle which may transport significant amounts of lead to the home (Barltrop, 1972b).

In contrast with the developed countries, the low density of petrol-engined traffic suggests that exhaust fumes are unlikely to contribute significantly to the intake of lead by children in Uganda. This appears to be supported by the values of urinary lead excretion found in two groups of Ugandan 
adult males resident in an urban area, one of which was occupationally exposed to leaded gasoline. Neither the exposed group nor the occupationally unexposed controls excreted abnormal amounts of lead when compared to unexposed adults elsewhere (Coles, 1971).

The overall information, therefore, indicated the possibility of excessive absorption of lead by individual children in Uganda and accordingly, this investigation was begun.

\section{Methods}

In a preliminary study the dietary intake of lead was determined by analysing specimens of faeces passed by normal children 3 to 4 years old who attended outpatients with their mothers. The faeces were collected and dried as described by McCance, Rutishauser, and Boozer (1970) before being taken to England for analysis. There, an aliquot was taken for wet digestion using a perchloric/nitric acid mixture, and analysed for lead by a semiautomated alkaline dithizone method (Browet and Moss, 1965). Specimens of the foods eaten at home and further samples of faeces were obtained from one of these children.

Specimens of bone were subsequently obtained sequentially from a series of 21 unselected necropsy examinations on young children. In each case a length of the 5 th rib was preserved at $-20^{\circ} \mathrm{C}$ pending transport to England. Similar material was obtained at 62 necropsies on children aged 0 to 10 years held at The Hospital for Sick Children, Great Ormond Street, and the Queen Elizabeth Hospital for Children, Hackney; and, in addition, 15 specimens of vertebrae were collected through the National Strontium Monitoring Survey under the auspices of the MRC Radiobiological Unit, Harwell. The periosteum and adventitious material were removed, and samples from the vertebrae or the midshaft region of the ribs weighing 1 to $2 \mathrm{~g}$ were wetashed as above and the residue taken up in $1 \mathrm{~N} \mathrm{HCl}$ (Analar). Lead was determined by means of anodic stripping voltammetry using a Chemtrix polarograph assembly and a stationary mercury drop. The calcium content of the dissolved residue was determined with a Pye-Unicam SP 90A atomic absorption spectrophotometer. The lead in the bones was expressed in terms of bone mineral as $\mu \mathrm{g} \mathrm{Pb} / \mathrm{g} \mathrm{Ca}$.

\section{Results}

The Table shows the lead content of faeces of the 4 children attending outpatients, together with the mean and upper limit of the normal findings in children in the United Kingdom. 3 of the children passed faeces containing lead in excess of the upper limits usually accepted as normal, suggesting a recent abnormal dietary exposure. One of them (Case 4) excreted lead in excess of $1.0 \mathrm{mg}$ per specimen which, sustained throughout a period of 4 to 5 months, would have been likely to result in
TABLE

Quantities of lead found in faeces of 4 children (ages 3-4 years) and in the home foods of one of them (Case 4)

\begin{tabular}{|c|c|c|c|}
\hline Cases & $\begin{array}{c}\text { Lead } \\
\text { ( } \mu \mathrm{g} / \mathrm{stool} \\
\text { collected) }\end{array}$ & $\begin{array}{l}\text { Name of } \\
\text { food }\end{array}$ & $\begin{array}{c}\text { Lead } \\
(\mu \mathrm{g} / 100 \mathrm{~g} \\
\text { dry weight) }\end{array}$ \\
\hline $\begin{array}{l}\text { Ugandan children } \\
\text { Case } 1 \\
\text { Case } 2 \\
\text { Case } 3 \\
\text { Case } 4\end{array}$ & $\begin{array}{r}457 \\
528 \\
140 \\
1116\end{array}$ & $\begin{array}{l}\text { Matooke (fresh) } \\
\text { Matooke (cooked) } \\
\text { Beans (fresh) } \\
\text { Beans (stored) }\end{array}$ & $\begin{array}{l}15 \cdot 2 \\
31 \cdot 5 \\
37 \cdot 3 \\
28 \cdot 5\end{array}$ \\
\hline $\begin{array}{l}\text { U.K. children } \\
\text { Mean } \\
\text { Mean + 2 SD }\end{array}$ & $\begin{array}{l}123 \\
183\end{array}$ & $\begin{array}{l}\text { Groundnuts } \\
\text { U.K. limit for } \\
\text { dried vegetablest }\end{array}$ & $\begin{array}{l}29 \cdot 1 \\
10 \cdot 0\end{array}$ \\
\hline
\end{tabular}

^Barltrop and Killala (1967).

†Ministry of Food (1954).

symptomatic lead poisoning in a young child. These findings provided some evidence that excessive ingestion of lead in some of the local children might be contributing to their clinical problems. Further samples of Case 4's stools were obtained together with specimens of the foods grown and eaten at her home. The child was well clinically at re-examination and her faeces contained $132 \mu \mathrm{g} \mathrm{lead} / \mathrm{specimen}$ of faeces, which is within the limits of normal for U.K. children (Barltrop and Killala, 1967). Lead was detectable in the foodstuffs obtained from the home, and the Table shows that the content of all the samples exceeded acceptable limits compared with the standards for foodstuffs in the United Kingdom (Ministry of Food, 1954).

The increase in the lead content of matooke after cooking suggested that there may have been a small contribution of lead from the domestic utensils, but contributions from the water supply or other extraneous sources could not be excluded.

The Fig. shows the lead content of the 21 ribs taken at necropsy in Kampala compared with that found in the bones of 77 British children. No significant difference between the results for these two groups was noted, and within that age range there was no significant age-dependent variation in the lead content of bone. There were some rather high findings in a few of the Ugandan children, and though the mean of the group $(42.9 \mu \mathrm{g} / \mathrm{g} \mathrm{Ca} \pm \mathrm{SD}$ $30 \cdot 1)$ was slightly higher than that for the British children $(31.8 \mu \mathrm{g} / \mathrm{g} \mathrm{Ca} \pm \mathrm{SD} 21 \cdot 4)$ the difference was not significant.

\section{Discussion}

The objective of this study was largely exploratory. The initial studies supported the idea 


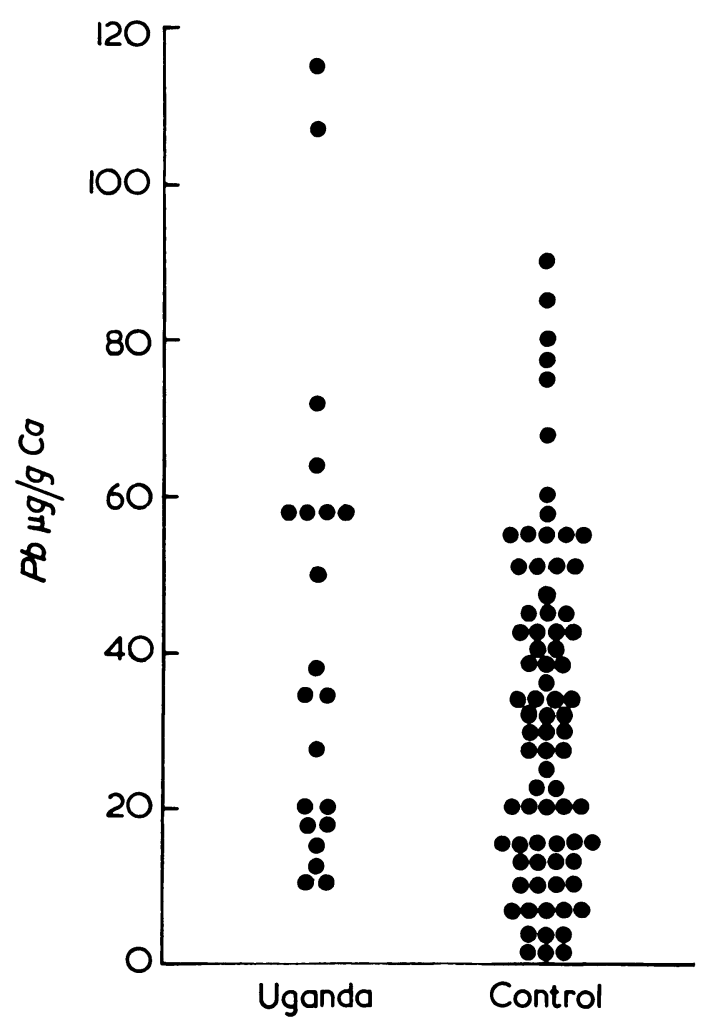

FIG.-Lead found in the bones of 21 Ugandan and 77 British children.

that excessive intakes of lead might not be uncommon in the population served by the hospital since 3 of 4 children seemed to be ingesting undesirable amounts of lead from their domestic environment. Subsequent examinations of the bones of other children did not confirm that their lead intakes had resulted in excessive absorption of lead. The slightly increased values found in some of the Ugandan bones may conceivably be due to the low calcium intakes of the children and to poor mineralization of the skeleton in consequence. It has been suggested that progressive accumulation of lead in the skeleton may continue throughout life (Horiuchi, Horiguchi, and Suekane, 1959). There was no evidence for this in the 'control' children used for this study, but the numbers in each age group were too small to make the results conclusive. The lead found in the bones of both groups of children, however, was greater than the values reported by Barry (1972) on 6 U.K. children aged less than 16 years, but was comparable to the collected data for nonexposed adults reported by Jaworowski (1967). The relatively greater calorie requirements of young children may result in a correspondingly greater skeletal accumulation in the younger age groups (Barltrop, 1972a). Though no increase in soft tissue burden was shown, it seems that the exposure of children to lead in developing countries cannot be disregarded.

The material required for this work was obtained through the MRC's Infantile Malnutrition Research Unit, Kampala, between 1967 and 1970.

We are indebted to Drs. R. Owor, N. France, and J. F. Loutit, and Professor A. Claireaux for their assistance. Miss Ingrid Rutishauser did much of the early work in Kampala; and Miss Thornely and Mr. R. Spencer-Jones assisted later in the collection of the bones and in their transportation to England, and the latter's expenses were defrayed by a grant from The Royal Society. The analyses were made by Miss E. Thonger. D.B. is a Wellcome Senior Fellow in Clinical Science.

\section{REFERENCES}

Barltrop, D. (1968). Lead poisoning in childhood. Postgraduate Medical fournal, 44, 537.

Barltrop, D. (1972a). Children and Environmental Lead in the Environment, p. 52. Ed. by P. Hepple. Institute of Petroleum, London.

Barltrop, D. (1972b). Sources and significance of environmental lead for children. In Proceedings of the foint $C C E / E P A$ International Symposium on Environmental Health Aspects of Lead, October 1972, Amsterdam.

Barltrop, D., and Killala, N. J. P. (1967). Faecal excretion of lead by children. Lancet, 2, 1017.

Barry, P. (1972). A comparison of lead concentrations in human bones and in soft tissues. In Proceedings of the foint $C C E / E P A$ International Symposium on Environmental Health Aspects of Lead, October 1972, Amsterdam.

Browet, E. V., and Moss, R. (1965). Manual and semi-automatic methods for the determination of the lead content of urine. Analyst, 90, 715.

Coles: G. V. (1960). Report of the factories inspectorate of the labour department for the year 1959. In Annual Report of the Labour Department for the Year Ended 31 December, 1959, Entebbe.

Coles, G. V. (1971). An investigation into an occupational lead hazard. In Annual Scientific Conference of the East-African Medical Research Council, January 1971, Kampala.

Horiuchi, K., Horiguchi, S., and Suekane, M. (1959). Studies on the industrial lead poisoning. Osaka City Medical fournal, 5, 41.

Jaworowski, Z. (1967). Stable and radioactive lead in environment and human body. NEIC Review Report, No. 29, Warsaw.

McCance, R. A., Rutishauser, I. H. E., and Boozer, C. N. (1970). Effect of kwashiorkor on absorption and excretion of $\mathrm{N}$, fat, and minerals. Archives of Disease in Childhood, 45, 410.

Ministry of Food (1954). Food Standards Committee, Report on Lead. H.M.S.O., London.

Correspondence to Dr. D. Barltrop, Paediatric Unit, St. Mary's Hospital Medical School, London W.2. 